\title{
The Late-Holocene climate change, vegetation dynamics, lake-level changes and anthropogenic impacts in the Lake Urmia region, NW Iran
}

\author{
Taravat Talebi a , Elias Ramezani ${ }^{\text {b. * }}$, Morteza Djamali ${ }^{c}$, Hamid Alizadeh Ketek Lahijani ${ }^{\mathrm{d}}$, \\ Alireza Naqinezhad ${ }^{\mathrm{e}}$, Kamaleddin Alizadeh ${ }^{\mathrm{f}}$, Valérie Andrieu-Ponel ${ }^{\mathrm{c}}$ \\ ${ }^{a}$ Urmia University, Urmia, Iran \\ b Department of Forestry, Faculty of Natural Resources, Urmia University, Urmia, Iran \\ ' IMBE, Aix-Marseille Université, CNRS, IRD, Avignon Université, Europôle Méditerranéen de l'Arbois, BP 80, F-13545 Aix-en-Provence cedex 04, France \\ d Iranian National Institute for Oceanography and Atmospheric Science (INIOAS), Tehran, Iran \\ e Faculty of Sciences, University of Mazandaran, Babolsar, Mazandaran, Iran \\ ${ }^{\mathrm{f}}$ Department of Palynology and Climate Dynamics, University of Göttingen, Göttingen, Germany
}

Keywords:

Holocene

Rapid climatic changes

Anthropogenic activities

Vegetation history

Riella

Lake Urmia

\section{A B S T R A C T}

Two short (100 and $175 \mathrm{~cm}$-long) sediment cores from the southwestern corner of Lake Urmia provide a record of vegetation dynamics, lake-level changes and the role of climate and humans in shaping the landscape around Lake Urmia over the last 2550 years. Relatively low values of arboreal pollen (AP), and substantial values of Artemisia pollen from 2550 to 1500 cal BP indicate the prevalence of steppe vegetation and relatively arid climate in the area. However, a prominent peak of Riella spores may indicate a short-lived lake-level rise for the period 1900-2000 cal BP. The next period, 1500-550 cal BP, is characterized by substantial rise in AP, particularly Quercus, and a sharp decline of Artemisia, Chenopodiaceae/Amaranthaceae and wetland pollen types, suggesting the expansion of oak forests under a rather moist climate and/or a decline in agro-sylvo-pastoral practices in the area. Agricultural activity in the area can be inferred from sporadic occurrences of Vitis, Ricinus and Juglans pollen from the beginning of the record. The rise of saline habitat pollen types between 1100 and $800 \mathrm{cal} \mathrm{BP}$, along with increased values of magnetic susceptibility and organic matter, suggest a lower water level and the subaerial exposure of saline mud flats, which could favour the re-colonization of chenopods and other halophytes around the margins of the lake. Thus, the Medieval Climatic Anomaly seems to be warmer-than-present in the Lake Urmia region. From 450 to 150 cal BP, the decline in Quercus and high values of Artemisia, along with higher lake levels and high magnetic susceptibility values, could be associated with the Little Ice Age. Since 500 cal BP, Quercus and Riella steadily decline and fade out towards the surface of the core, whereas pollen types attributable to steppe and desert vegetation increase. A prominent increase in organic matter in the uppermost part of the record could be associated with a lower lake level and the expansion of wetland vegetation in the recent past. Our findings suggest that the regional forest coverage in the highlands of Zagros and Azerbaijan has reached its minimum during recent decades, while Urmia's lake level dropped dramatically (increasing its water salinity) most likely as a function of extensive anthropogenic activities and general climate aridification.

\section{* Corresponding author.}

E-mail addresses: valinor2000@yahoo.com (T. Talebi), e.ramezani@urmia.ac.ir, elias.ramezani@gmail.com (E. Ramezani), morteza.djamali@imbe.fr (M. Djamali) lahijani@inio.ac.ir (H.A.K. Lahijani), A.Naqinezhad@umz.ac.ir, anaqinezhad@gmail. com (A. Naqinezhad), kamal.alizadeh@biologie.uni-goettingen.de, kamal. alizadeh@gmail.com (K. Alizadeh), valerie.andrieu-ponel@imbe.fr (V. AndrieuPonel).

\section{Introduction}

Southwest Asia, especially the Eastern Mediterranean and the Middle East, have a long history of human settlements and agropastoral economies (Robinson et al., 2006; Shackley, 2006; Klinge and Fall, 2010; Katkar, 2011; Tsanova, 2013). Climate variability is considered to have played an important role in socio-cultural and socio-economic changes of early societies in the Middle East. The 
impact of climate on the collapse and renaissance of early civilizations has been discussed by several investigators (e.g. Manzanilla, 1997; Cullen et al., 2000; Robinson et al., 2006; Issar et al., 2012; Leroy, 2013). Many studies have explored Late-Quaternary and Holocene environmental changes in Southwest Asia, including the Eastern Mediterranean and the Middle East (e.g. Wick et al., 2003; Djamali et al., 2008a; Kuzucuoğlu et al., 2011; Woodbridge and Roberts, 2011; Ponel et al., 2013; Litt et al., 2014; Tudryn et al., 2013). Almost all palaeoclimatic records from the region are in agreement over the pronounced changes in climate after the Younger Dryas to a warm Early-Holocene around 10,000 cal BP (e.g. Snyder et al., 2001; Wick et al., 2003; Wasylikowa, 2005; Robinson et al., 2006; Stevens et al., 2012). Several records reveal that an arid early Holocene transitioned to more humid and warmer climatic conditions at $\mathrm{ca} .8000 \mathrm{BP}$, when trees started to expand across the surrounding uplands in Eastern Mediterranean and Anatolia towards 6500 BP (Bottema, 1986; Griffiths et al., 2001; Wick et al., 2003; Wasylikowa, 2005; Messager et al., 2013; Joannin et al., 2014). Since high-resolution multi-proxy Late-Holocene records for this region are scarce, synchronizing a single climatic event across the available palaeoclimate data is challenging. Messager et al. (2013) and Kuzucuoğlu et al. (2011) suggest that an arid phase occurred around 3000 cal BP at Lake Paravani in Georgia and Lake Tecer in central Anatolia, while Wick et al. (2003) showed this phase was established in the Lake Van area after 4000 cal BP. Palaeoclimatic records inferred from several investigations in the Eastern Mediterranean (Kaniewski et al., 2011; Kuzucuoğlu et al., 2011; Woodbridge and Roberts, 2011; Roberts et al., 2012) and northern Iran (Ramezani et al., 2008) suggest a shift towards warmer and/or wetter period during the Medieval Climate Anomaly (MCA) from 1100 to 750 BP (cf. Bradley et al., 2003). Subsequently evidence of a relatively wet and cold climate can be detected in the Eastern Mediterranean and northern and northwestern Iran between 800 and $150 \mathrm{BP}$, coincident with the Little Ice Age (LIA) (Ramezani et al., 2008; Djamali et al., 2009a; Kuzucuoğlu et al., 2011; Leroy et al., 2011; Woodbridge and Roberts, 2011; Naderi Beni et al., 2013).

As the first palynological study on Lake Urmia, Bottema (1986) attempted to reconstruct the Late-Pleistocene vegetation and climate history of northwestern Iran. However, this study suffered from relatively high chronological uncertainty. More recently, Djamali et al. (2008a) provided a 200,000-year-long record of environmental changes around Lake Urmia from marine isotope stage 7a (MIS-7a) to the Early-Holocene, based on pollen assemblages from two long cores. This study shows that the Late Glacial to Early-Holocene was dominated by general aridity (Djamali et al., 2008a), partly as a result of the intensification of subtropical anticyclonic system over Iranian plateau, which, in turn, indirectly controlled the early Holocene intensification of the Indian monsoon (Djamali et al., 2010). Mid-Late Holocene investigations in northwestern Iran suffer from low-resolution and/or insufficient dating, which hamper the accurate reconstruction of vegetation history and climatic changes (Djamali et al., 2008a).

The aims of this paper are to: 1 ) reconstruct the Late-Holocene climate of the Urmia Basin; 2) assess the extent of anthropogenic modification of the basin's vegetation through time; 3 ) track changes in wetland and halophyte vegetation under the influence of changing lake levels.

\section{Materials and methods}

\subsection{Physical settings}

Lake Urmia (Fig.1), ca. $1273 \mathrm{~m}$ asl (AghaKouchak et al., 2015), is the largest Iranian internal water body and one of the world's largest hypersaline lakes. It was designated as a National Park in 1975 and is a Biosphere Reserve protected by the Ramsar Convention (Ramsar Sites Information Service (RSIS), 2015). Earlier investigations (e.g. Kelts and Shahrabi, 1986) report an average area of more than $5000 \mathrm{~km}^{2}$ for the lake and $52,700 \mathrm{~km}^{2}$ for its basin, comprising 3.25\% of the total land area of Iran. Recent data, however, show a progressive decline in the lake's surface area since 1995, e.g. $2366 \mathrm{~km}^{2}$ in August of 2011 (Anonymous, 2012), to ca. $1750 \mathrm{~km}^{2}$ in spring 2015 (Personal communication, Dr. Naser Agh, Urmia Lake Research Institute, Urmia University). This has resulted in a progressively decreasing water depth, from 8 to $12 \mathrm{~m}$ in the 1980s (Kelts and Shahrabi, 1986) to $1.5 \mathrm{~m}$, its springtime maximum in recent years (Dr. Naser Agh, pers. comm.). At the same time its salinity has increased from 217 to more than $300 \mathrm{~g}$ per litre (Anonymous, 2012; AghaKouchak et al., 2015).

Geologically, the lake has formed in a depression made by interaction of Tabriz Fault and the Great Zagros Fault (Shahrabi, 1994). The geology of the lake basin is very diverse and includes Precambrian-Paleozoic metamorphic rocks, Cretaceous limestone, Tertiary volcanics and volcaniclastics and Miocene marine limestones (Kelts and Shahrabi, 1986; Shahrabi, 1994). This shallow lake is surrounded by a range of high mountains, particularly the Sahand complex. Almost 60 permanent and seasonal rivers and streams, as well as many underground springs feed the lake (AghaKouchak et al., 2015). Since 1995, the natural environment of the lake has been threatened by rapid decline in water inflow to the lake. While some groups blame climate change for recent water scarcity, the issue seems to predominantly attributed to extensive anthropogenic activities, such as the construction of the Shahid Kalantari Causeway across the lake and 56 reservoir dams in the lake's watershed area, as well as excessive exploitation of the groundwater (Sima and Tajrishy, 2013; AghaKouchak et al., 2015, Iran Water Resources Management (WRM), 2015).

\subsection{Climate and vegetation}

According to the Köppen climate classification, most parts of the Lake Urmia basin are under a semi-arid climate and experience cold winters, hot-dry summers and chilly autumns (Nourani and Sayyah Fard, 2012). The 60-year averages of annual temperature and precipitation recorded at Urmia weather station, located $10 \mathrm{~km}$ west of Lake Urmia, are $11.6{ }^{\circ} \mathrm{C}$ and $339 \mathrm{~mm}$, respectively. Precipitation occurs mostly in winter and spring (Islamic Republic of Iran Meteorological Organization (IRIMO), 2015).

Based on available literature (Zehzad, 1989; Asri and Ghorbanli, 1997; Asri, 1999; Asem et al., 2014) and our own floristic surveys (2010, 2011), approximately 300 vascular plant taxa occur on the islands of the lake and in the lake's surroundings. The vegetation of the Lake Urmia area is chiefly composed of halophytic and halotolerant vegetation, dominated by Amaranthaceae species and halophytic grasses as the most prominent part of its flora. This type of vegetation constitutes the first zone of vegetation surrounding the lake and its islands. The delimitation of plant communities and detailed zonation within this vegetation type is difficult and a complex of factors - such as salinity, soil moisture, topography, stream water inflow, the relationship between groundwater and lake shore, interspecies competition and the human interference and grazing - all affect the distribution of plant communities and their establishment (Kelts and Shahrabi, 1986; Asri, 1999; Djamali et al., 2008b). Nevertheless, a total of 30 different plant communities are grouped into ten main physiognomical/ecological categories (Asri and Ghorbanli, 1997; Djamali et al., 2008b) in the halophytic and halo-tolerant vegetation zone: 


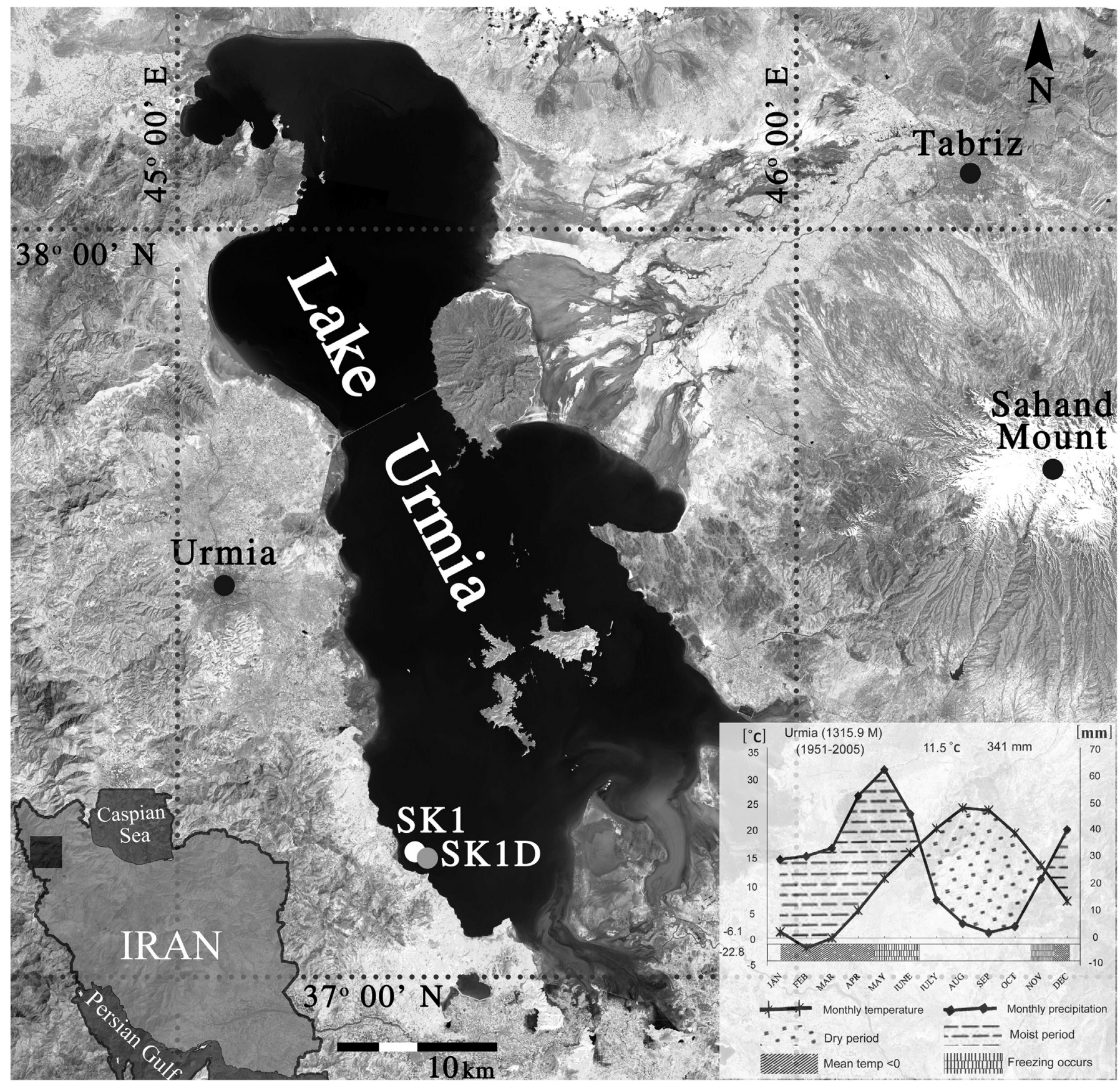

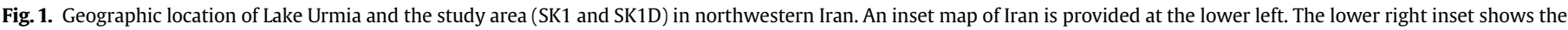
climate diagram of the Urmia meteorological station (data from IRIMO, 2015). The map was produced using Landsat 8 (2013) natural colour composite.

(1) Semi-woody shrub and perennial halophytic communities dominated by Halocnemum strobilaceum (Pall.) M. Bieb. on muddy and dry salty flats; (2) Annual halophytic communities on disturbed or temporary moist and inundated soils dominated by Suaeda spp., Petrosimonia spp., Halimocnemis rarifolia (Koch) Akhani; (3) Saltmarsh brushwood communities dominated by Tamarix spp. in shrub layer and Aeluropus littoralis (Gouan) Parl. in herb layer; (4) Rush and herbaceous perennial halophytic communities dominated by Juncus spp. and Puccinellia spp.; (5) Rush and herbaceous perennial halo-tolerant communities dominated by Agrostis stolonifera L.: (6) Hydrophilous halo-tolerant communities on margins of salty and brackish swamps, streams and areas with high groundwater table dominated by Phragmites australis (Cav.) Trin ex Steud. and Bolboschoenus maritimus (L.) Palla; (7) Annual hygro-halophytic communities on the lake shores dominated by Salicornia sp. and Suaeda crassifolia Pall.; (8) Disturbed salty places dominated by Alhaji maurorum Medlik., Caroxylon (Salsola) dendroides (Pall.) Tzvelev and Lycium ruthenicum Murray; (9) Patches of halophytic shrub communities on salty and sandy coastal parts of the islands of Lake Urmia dominated by Nitraria schoberi L.; (10) Hydrophytic communities dominated by Alisma plantagoaquatica L. 
These halophytic vegetation groups are surrounded by steppic vegetation of Artemisia fragrans Willd., along with shrubs and thorny cushion plants in the upland areas.

\subsection{Sampling}

The sampling site is a peripheral pond ( $1284 \mathrm{~m}$ asl, $37^{\circ} 07^{\prime} 49.5^{\prime \prime}$ $\left.\mathrm{N}, 45^{\circ} 26^{\prime} 48.7^{\prime \prime} \mathrm{E}\right)$ located approximately $65 \mathrm{~km}$ south of Urmia city (Fig. 1). The water table at the site at the time of core collection was lowered, but the sediments were still soft and marshy, covered by hydrophytic plant species.

In the spring and summer of 2012, we studied the flora and vegetation of the surface and margins of the studied site. A total of 115 plant taxa were identified to species level using available Floras, particularly Rechinger (1963-2010). The most abundant species are listed in Table 1.

Table 1

The most abundant plant taxa encountered on the surface and margins of the coring site.

\begin{tabular}{ll}
\hline Surface & Margin \\
\hline Salicornia sp. (see Akhani, 2008) & Juncus gerardi Loisel. \\
Suaeda maritima Dumort. & Juncus maritimus Lam. \\
Bulboschoenus affinis Drobow & Scirpoides holoschoenus (L.) Sojak \\
Cyperus distachyos All. & \\
Phragmites australis (Cav.) Steud. & \\
Carex divisa Huds. & \\
\hline
\end{tabular}

In March 2012, a 100-cm long core (SK1) was retrieved using a Russian-type chamber corer. In another attempt in the spring of 2013, deeper layers were reached; so that a $175-\mathrm{cm}$ long parallel core, designated SK1D, was collected ca. 1-2 m distance from the first one. The cores were wrapped in plastic film, placed in half PVC core liners and stored at $4{ }^{\circ} \mathrm{C}$.

\subsection{Physico-chemical and palynological analyses}

Magnetic susceptibility (MS) was measured using Bartington MS2C, while organic matter $(\mathrm{OM})$ and calcium carbonate $\left(\mathrm{CaCO}_{3}\right)$ were estimated using loss-on-ignition (Heiri et al., 2001). These measurements were performed on the SK1 profile at the Iranian National Institute for Oceanography and Atmospheric Science (INIOAS).

Palynological sub-samples of $4 \mathrm{~cm}^{3}$ were taken at $4-\mathrm{cm}$ intervals from SK1. Additionally, 12 sub-samples were collected from the lower part (96-175 cm) of SK1D: $10 \mathrm{~cm}$ intervals for the lower $55 \mathrm{~cm}$ and $4 \mathrm{~cm}$ for the remaining upper part. Sample preparation was carried out at the Institut Méditerranéen de Biodiversité et d'Ecologie, (IMBE) in Marseille, following the standard technique of Fægri and Iversen (1989). Pollen counting was performed at the faculty of Natural Resources, Urmia University, under an OlympusCX31 light microscope with $400 \times$ magnification. Higher magnifications were used for identifying problematic pollen grains. Apart from the sample at $75 \mathrm{~cm}$ depth, where pollen concentration was extremely low, an average of 256 pollen grains attributable to terrestrial plants were counted per sub-sample. Pollen-morphological types are displayed in the text by SMALL CAPITALS in order to clearly distinguish them from plant taxa (Joosten and de Klerk, 2002). Common pollen and spores were identified and named after (M): Moore et al. (1991), (B): Beug (2004), (P): the Northwest European Pollen Flora (Punt et al., 1976-2003), and with the help of the reference slides of the faculty of Natural Resources, Urmia University. The spores of Riella were identified after Djamali et al. (2008b). Riella (Riellaceae), as a monogeneric taxon of disjunct worldwide distribution (except Antarctica), is an aquatic submerged liverwort growing in shallow, fresh to brackish temporary, or rarely permanent, ponds and streams. Flourishing in Mediterranean-type climates, its centre of dispersal and origin is presumably the Mediterranean basin (Djamali et al., 2008b; Segarra-Moragues et al., 2012; Puche and Segarra-Moragues, 2013).

Microfossil percentages were calculated relative to the pollen sum, including pollen types that are assumed to originate from trees and shrubs (AP) and dryland (i.e. well-drained upland) herbs (NAP). Pollen of aquatics, Amaranthaceae (including CHENOPODIACEAE-type pollen) and Poaceae were excluded from the sum due to their overrepresentation in the local flora at the sampling site.

We used TILIA 1.7.16 software (Grimm, 2011) for calculation and presentation of the palynological data. In this study, we considered the percentage values of Vitis, Ricinus, Juglans, Olea and Salix (summed up as 'Cultivated trees') as indications for fructicultural practices. Also, the cumulative curve of Plantago lancEOlata-Type and RUMEX ACETOSA TYPE (i.e. ruderal and nitrophilous plants) is thought to relate to human impact on natural vegetation. These types may point to disturbed areas along pathways and farmlands (Djamali et al., 2009a).

\subsection{Radiocarbon dating and age-depth model}

Four AMS (accelerator mass spectrometer) C-14 dates were delivered by Poznań Radiocarbon Laboratory from bulk organic sediments (no macroremains found) collected at 30, 48, 151 and $183 \mathrm{~cm}$ depths from the SK1D core (Table 3). Since chemical and biochemical precipitation of dissolved carbonates originating from old geological formations may cause a "reservoir effect" to modify the radiocarbon ages obtained from bulk sediments, the samples were treated by $10 \% \mathrm{HCl}, 48 \% \mathrm{HF}$, and $37 \%$ concentrated $\mathrm{HCl}$ successively to remove this chemical/biochemical carbonate fraction, as well as siliciclastic materials. No alcohol or other carbon-based organic compounds were used to avoid adding carbon to the sediment. This extraction technique helps to concentrate the organic matter produced through purely biological processes and is considered free of any reservoir effect.

Table 2

Simplified lithostratigraphic description of SK1 and SK1D cores; colors derived from Munsell soil color charts (1975).

\begin{tabular}{lcl}
\hline & Depth $(\mathrm{cm})$ & Description \\
\hline Section B & $1-7$ & Slightly decomposed to undecomposed brown peat \\
& $7-19$ & Highly decomposed dark brown peat \\
& $19-27$ & Dark grey clay \\
& $27-35$ & Dark grey sandy clay \\
& $35-45$ & Grey to greenish clay \\
Sections B and A & $45-55$ & Dark grey sand \\
& $55-71$ & Greenish-grey clay with sand and rock fragments \\
\hline
\end{tabular}


Table 3

Results of radiocarbon and calibrated ages of core SK1D.

\begin{tabular}{llrll}
\hline Depth $(\mathrm{cm})$ & Lab. no. & \multicolumn{1}{c}{${ }^{14} \mathrm{C}$ yr BP } & Cal. yr BP & Remark \\
\hline 30 & Poz-65675 & $110.1 \pm 0.37 \mathrm{pMC}$ & -47 & - \\
48 & Poz-65676 & $845 \pm 30 \mathrm{BP}$ & 714.7 & - \\
151 & Poz-61475 & $875 \pm 30 \mathrm{BP}$ & 2203.2 & $0.5 \mathrm{mgC}$ \\
183 & Poz-61476 & $2715 \pm 30 \mathrm{BP}$ & 2695.9 & - \\
\hline
\end{tabular}

An age-depth model was plotted in $\mathrm{R}$ studio (version 3.0.1; $\mathrm{R}$ Development Core Team, 2013) using Bacon (Blaauw and Christen, 2011), which is based on Bayesian statistics, to reconstruct accumulation histories for deposits (Fig. 2). The IntCal13 radiocarbon calibration curve was used to calibrate $\mathrm{C}^{14}$ dates and Student's t distribution was assigned, making the chronological modeling process much more robust against outlying dates.

\section{Results}

\subsection{Lithology}

Simplified lithostratigraphic descriptions of the cores are presented in Table 2 and Fig. 4. The cores mainly consist of soft clayey mud. Rather coarse, granular detrital material, probably in-washed from surrounding uplands, constitutes the mid-part $(45-71 \mathrm{~cm})$ of the profile. Major accumulation of organic materials occurs from the surface down to a depth of $19 \mathrm{~cm}$ below the surface. It seems that marsh vegetation on the exposed shores is an important contributor to organic matter accumulation in the SK record. The $\mathrm{MS}, \mathrm{CaCO}_{3}$ and $\mathrm{OM}$ time series are shown in the right panels of the pollen diagram (Fig. 4).

\subsection{Chronology}

Similar lithologies of the obtained adjacent sediment cores may permit us to safely use the age-depth model constructed for the SK1D for the composite result of both profiles. The combined SK1 and SK1D records, herein referred to as SK, provide an apparently continuous pollen record for the past 2550 years (Figs. 3 and 4). An age-depth model of the SK1D core is shown in Fig. 2. The chronology of core SK1D relies on three radiocarbon dates with the least contribution from the oldest possible age of the date at $30 \mathrm{~cm}$. Although using the Student's t-distribution approach means that dates often fit age-depth models, the ${ }^{14} \mathrm{C}$ date at $151 \mathrm{~cm}$ $(875 \pm 30 \mathrm{BP})$ was excluded from the age-depth model by Bayesian modeling, because of its poor fit with the overall sedimentation rate. The age-depth curve (Fig. 2) suggests a sedimentation rate of ca. $0.7 \mathrm{~mm} / \mathrm{yr}$ between 180 and $48 \mathrm{~cm}$ and $0.23 \mathrm{~mm} / \mathrm{yr}$ from $48 \mathrm{~cm}$ upwards.

\subsection{Palynological data}

Results of the pollen analyses are presented in Figs. 3-5. Upland vegetation (Fig. 3 ) is considered to be a reflection of the prevailing regional climatic condition, whereas the hygrophilous vegetation (Fig. 4) mostly reflects the prevailing conditions in the wetland area, such as changes in lake level. We thus created two separate zonations for AP-NAP and the Wetland and saline-Uncertain habitat types. By "uncertain habitat types", we refer to those pollen types that the ecological characteristics of their producing plants are unclear (e.g. Cyperaceae and Poaceae). Based on visual inspection, five local pollen assemblage zones (PAZ) and subzones were established for both the AP-NAP sequence (SK1-A - SK1-C; Fig. 3) and Wetland and saline-Uncertain habitat types sequence (SK1-1 - SK1-5; Fig. 4).
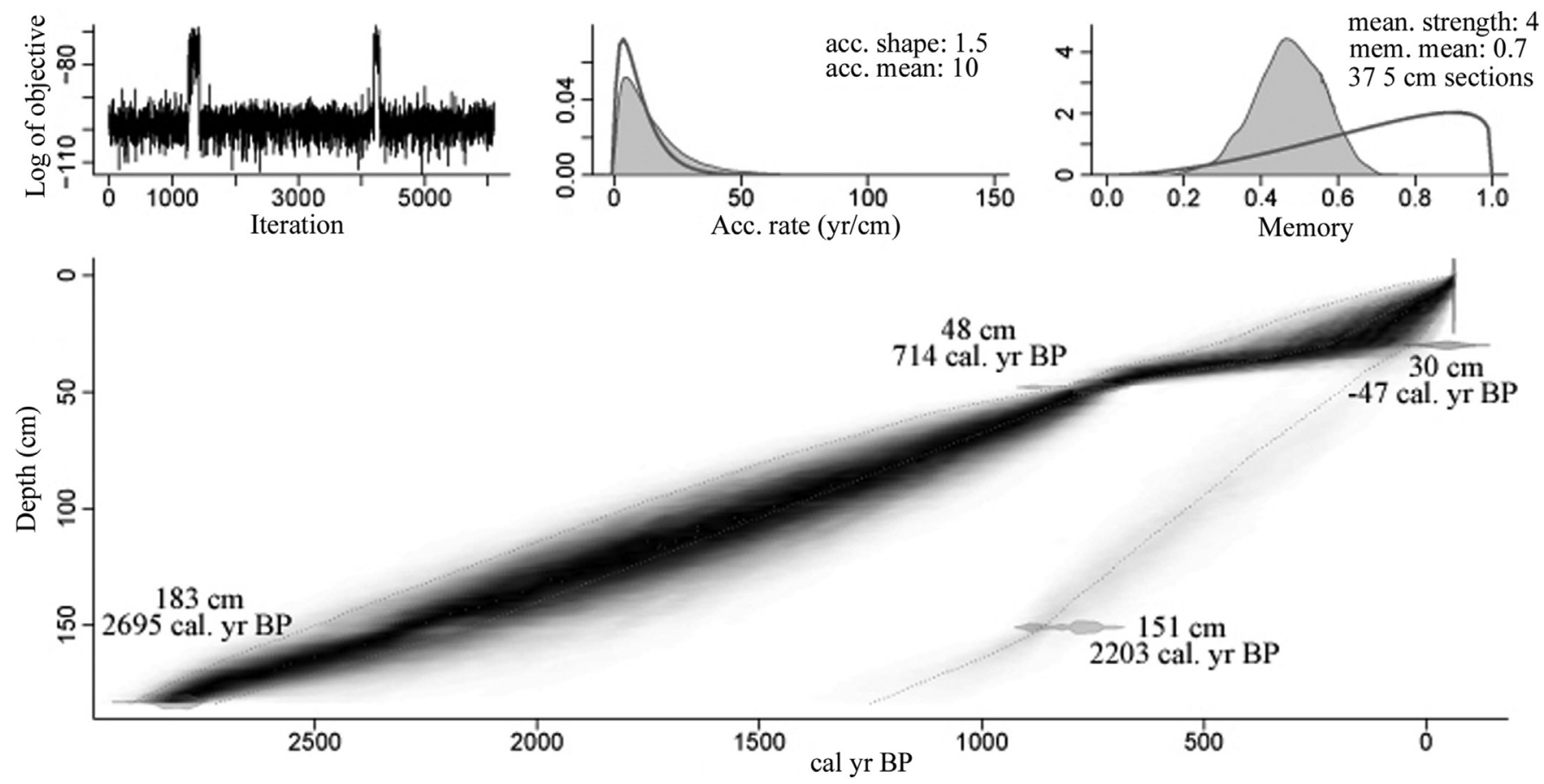

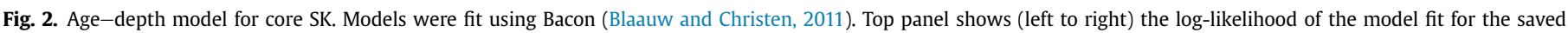

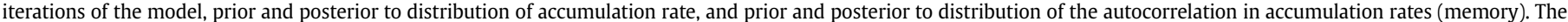

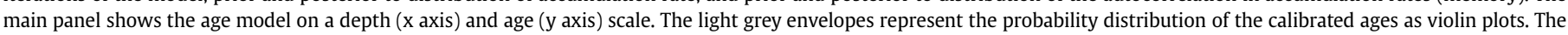
grey shading represents the probability of ages for any given depth. Dotted lines show the $95 \%$ highest probability density. 


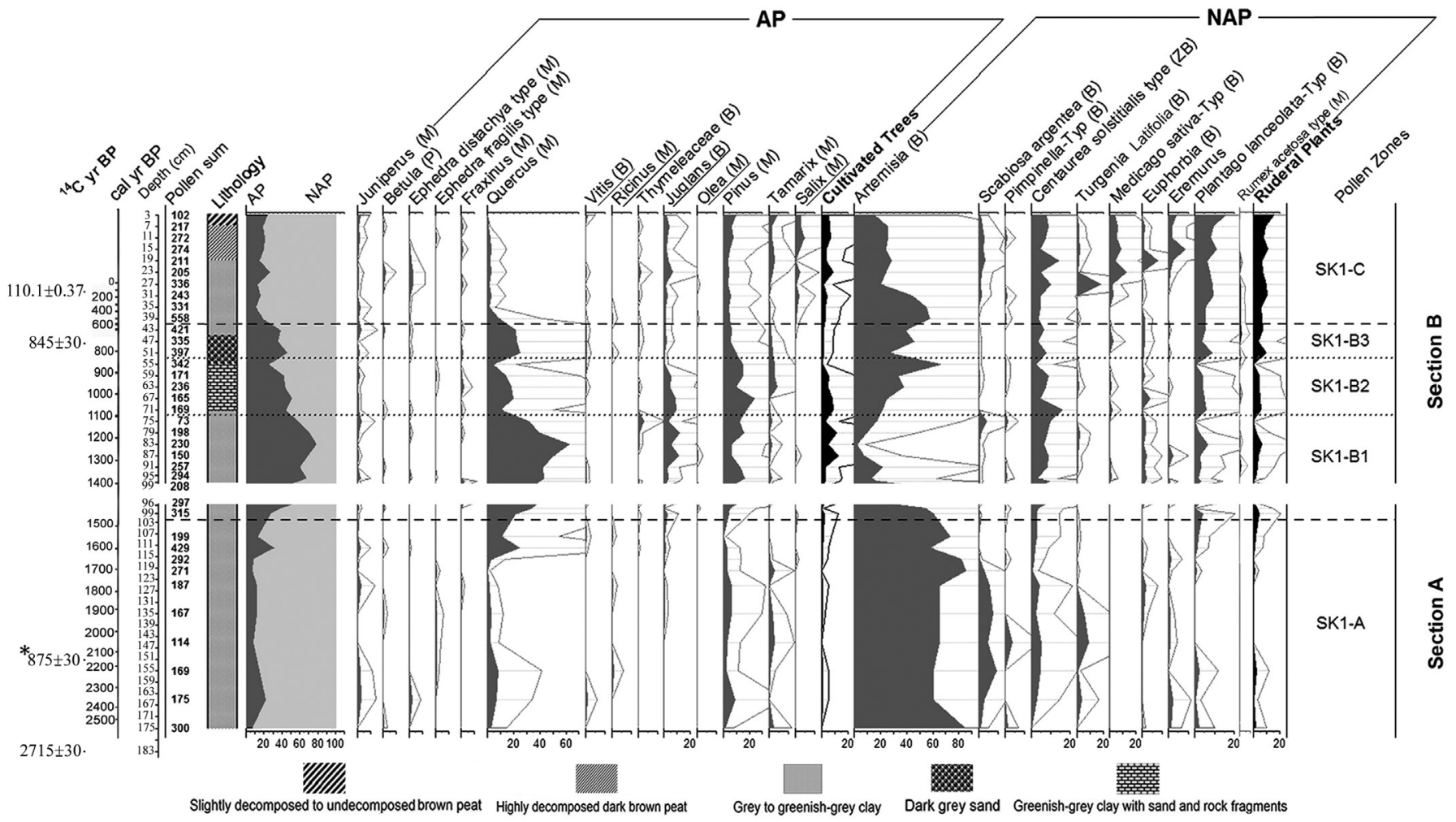

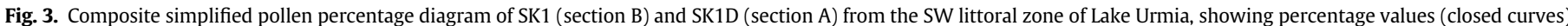

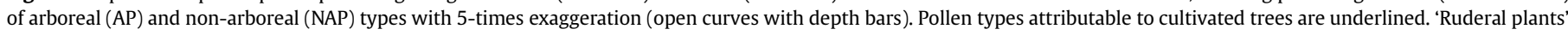

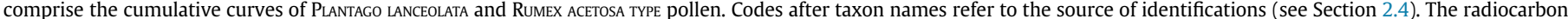
date $875 \pm 30$ is given an asterisk, indicating that it was excluded from the age-depth model (see Section 3.2).

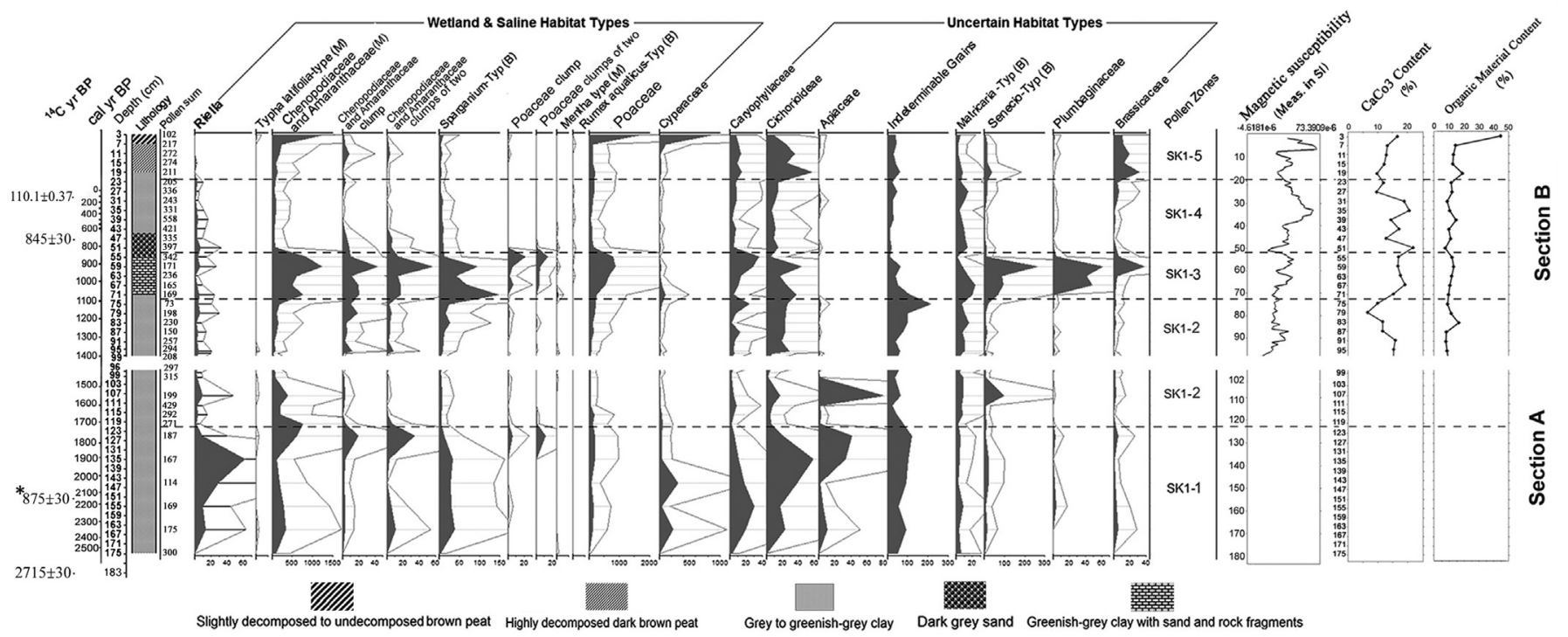

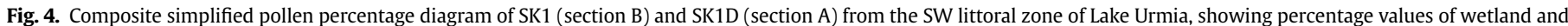

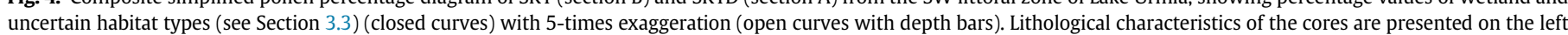

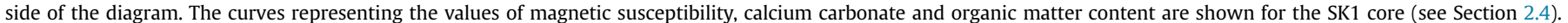

\subsubsection{Pollen record of the regional vegetation (AP-NAP diagram)}

The AP-NAP pollen diagram is divided into three pollen assemblage zones (PAZs) and three subzones based on variation of major taxa (Fig. 3).
3.3.1.1. PAZ SK1-A (175-102 cm; 2555-1474 cal BP). This zone consists predominantly (78-93\%) of non-arboreal pollen (NAP), with Artemisia being the most abundant. Other important, but less frequent, NAP include ScABIOSA ARGENTEA, CENTAUREA SOLSTITIALIS-TYPE, and 


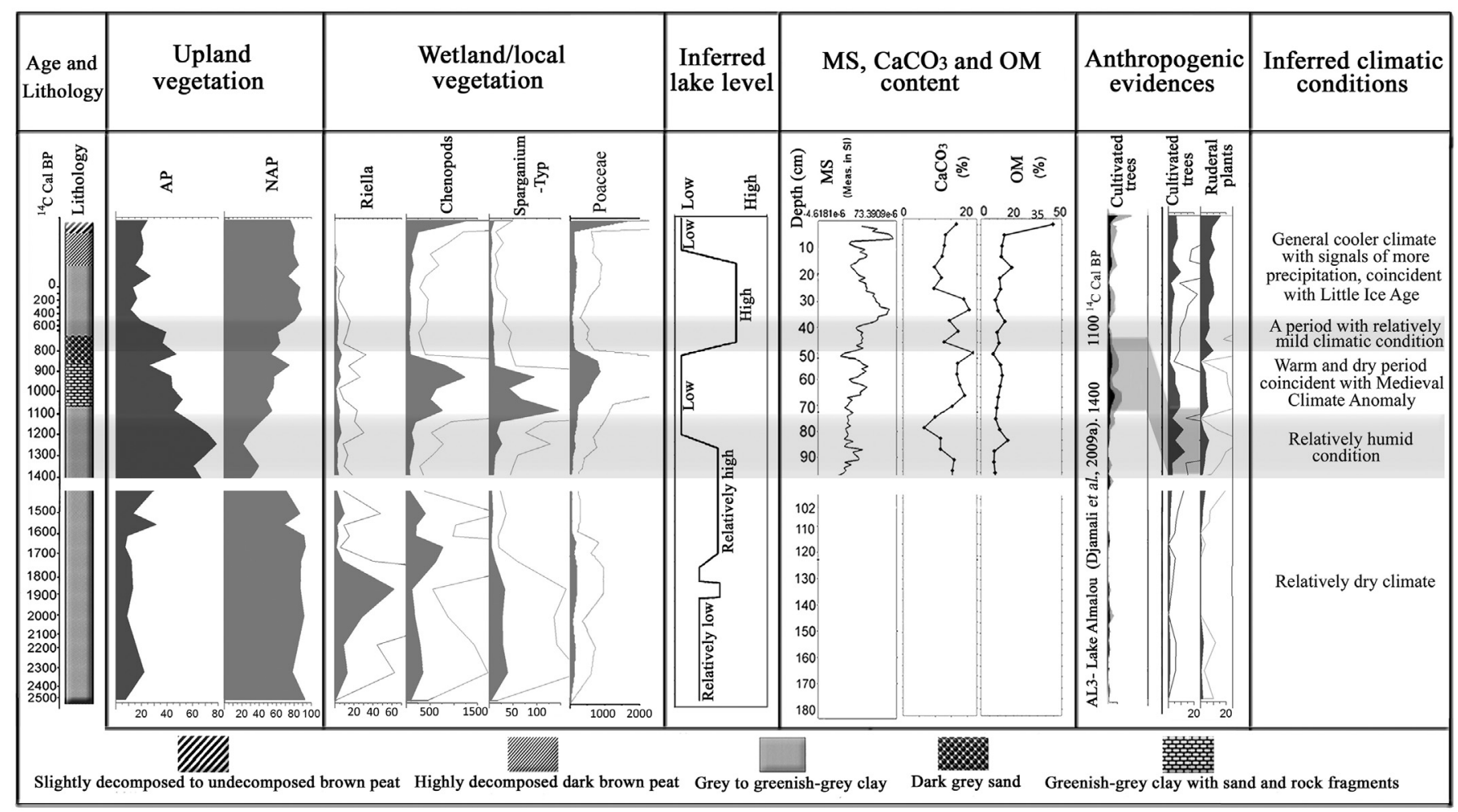

Fig. 5. Summary of the Late-Holocene environmental changes in Lake Urmia region, NW Iran.

TuRgenia latifolia. EREMURus exhibits a continuous though low-value curve. Plantago lanceolata-Type pollen is absent in the midst of the zone. Quercus displays relatively low values $(<1 \%)$ in most of the zone but peaks (24\%) close to the upper boundary. Pinus, JUNIPERUS, and TAMARIX are present with relatively low values in almost all spectra. The pollen types attributable to cultivated taxa, i.e. VITIS, Ricinus and Juglans (Fig. 3), are present occasionally; however, Juglans slightly increases near the upper limit of the zone.

3.3.1.2. PAZ SK1-B (102-41 cm; 1474-557 cal BP). This pollen assemblage zone, characterized by elevated proportions of arboreal pollen, may be subdivided into three sub-zones: SK1-B1, SK1-B2 and SK1-B3.

The SK1-B1 sub-zone (102-73 cm; 1474-1088 cal BP) starts with a sudden increase in AP (from 13\% to 79\%), to which QueRcus is the most abundant contributor. Between 1280 and 1171 cal BP, the pollen abundance of cultivated trees, mostly comprising of walnut, reaches up to $12 \%$, the highest value through the record. Single grains of OlEA were encountered. ArTEMISIA almost disappears in the middle of this subzone, where the ruderal plants and CENTAurea SOLSTITIALIS-TYPE exhibit a small peak.

The SK1-B2 sub-zone $(73-53 \mathrm{~cm} ; 1088-813 \mathrm{cal} \mathrm{BP})$ is characterized by substantial decline in AP, where values range from 26 to $52 \%$. QuerCus values vary between 4 and $25 \%$, while values for cultivated taxa progressively decrease from 8 to less than $1 \%$. PINUS values range between 12 and 24\%. TAMARIX shows a small peak (4\%) in the middle $(63 \mathrm{~cm})$ of the subzone. ARTEMISIA increases gradually and reaches its highest values (66\%) close to the upper boundary of the subzone.

The SK1-B3 sub-zone (53-41 cm; 813-557 cal BP) differs from SK1-B2 in its slightly higher proportions of QueRCus, lower PINUs and the almost absence of Juglans. The frequency of ruderal plants slightly increases. ARTEMISIA remains the most abundant NAP type.
PAZ SK1-C (41 cm to top of the core; $557-(-3)$ cal BP) is characterized by a dramatic decline in AP types. Quercus values are negligible and disappear altogether in the topmost layers. In contrast, cultivated trees increase slightly and Salix develops in the upper samples. ARTEMISIA is still the most frequent pollen type. Most other NAP types, including Centaurea solstitialis-Type, Medicago sativaTYPE, EUPHORBIA and EREMURUS, increase, particularly in the upper half of the zone.

\subsubsection{Wetland and uncertain habitat pollen diagram}

Zone SK1-1 (175-121 cm; 2555-1749 cal BP) is identified by grey to greenish-grey clay and characterized by high pollen percentages of wetland and halophytic plants. CHENOPODIACEAE-TYPE is the most abundant type, reaching values up to $c a$. $62 \%$ close to the upper boundary of the zone. Pollen clumps of this type were also observed, indicating the local presence of these taxa at the sampling site. Other important types of this ecological group are CyPeraceae and PoAcEAE, with values up to 306 and 195\% (percentages relative to upland pollen), respectively. RIELLA forms a prominent peak (62\%) in the upper half of the zone. SPARGanium-Type is present with values ranging from 3 to 38\%. Among pollen types corresponding to plants of uncertain habitats, CARYOPHYLLACEAE prevails in the lower half of the zone but is replaced by Cichorioideae and ApIACEAE in the upper half.

Zone SK1-2 (121-73 cm; 1749-1088 cal BP) is lithologically identical to the SK1-1 zone. Almost all pollen types attributable to wetland and/or halophytic plants decline substantially and start to increase again near to the next zone (SK1-3). Types of uncertain habitats are represented by a prominent peak of APIACEAE in the lower half and increased values of CICHORIOIDEAE, CARYOPHYLLACEAE, and MATRICARIA-TYPE in the upper half of the zone.

Zone SK1-3 (73-53 cm; 1088-813 cal BP) consists of greenishgrey clay with sand and sharp rock fragments. This zone is characterized by prominent peaks of wetland and halophytic types, i.e. 
Chenopodiaceae-Type (including clump forms), Sparganium-Type and Poaceae. Among the types from uncertain habitats, Caryophyllaceae, Cichorioideae, and Matricaria-Type substantially increase, while Senecio-Type (260\%), Plumbaginaceae (61\%) and Brassicaceae (37\%) reach their highest values throughout the entire record. APIACEAE disappear in this zone.

Zone SK1-4 (53-22 cm; 813-(-34) cal BP) is identified by intervals of dark grey sand and clay layers. This zone can be distinguished from the previous one by almost the disappearance of most pollen types attributable to wetland-halophytic plants and also by low values of types of uncertain habitats.

Zone SK1-5 (22-3 cm; -34-(-5) cal BP) is lithologically composed of dark grey clay in the lower part which grades into slightly to highly decomposed organic sediment in the upper part. Wetland-halophytic types, CHENOPODIACEAE-TYPE (1255\%), POACEAE (1715\%) and CYPERACEAE (875\%) reach their maximum values in the uppermost samples. Types from uncertain habitats are represented by high values of CICHORIOIDEAE and BRASSICACEAE.

\section{Discussion}

\subsection{Upland vegetation dynamics and climate change}

\subsubsection{Period between $2555-1474 \mathrm{cal} \mathrm{BP}(175-102 \mathrm{~cm})$}

The beginning of the record (zone SK1-A, Fig. 3) is exclusively dominated by ARTEMISIA, which, along with less abundant taxa such as Asteroideae, Cichorioideae, Caryophyllaceae, Brassicaceae and Ephedra (cf. van Zeist and Bottema, 1977; Joannin et al., 2014), may suggest the prevalence of steppe to desert-steppe vegetation around the southwestern part of Lake Urmia during this period. Previous palynological research also points to almost treeless landscape in west and northwestern Iran during this period (Bottema, 1986). Artemisia is a common and often dominant taxon in the modern steppe and desert-steppe vegetation of the Central Iranian Plateau (van Zeist and Bottema, 1977; Zohary, 1973). Pollen of Artemisia also shows significant values during the glacial period over the Eastern Mediterranean, the Near East (Bottema, 1986) and even Western Europe (Reille et al., 1998; Beaulieu et al., 2001). The significant contribution of Apiaceae to the vegetation composition during this period can be inferred from the relatively high values of e.g. TURGENIA LATIFOLIA (Fig. 3, but also see the curve of APIACEAE in Fig. 4). Members of this family are mainly insect-pollinated and normally underrepresented in pollen rain. This, together with the relatively high values of heavy, insect-pollinated SCABIOSA ARGENTEA (Fig. 3), might indicate the inwashing of these pollen types during periods of sparse woody vegetation. Different pollen types of APIACEAE also show extremely high values in the sediments of the last glacial period of Lake Urmia where their incorporation in the sediment was assigned to heavy runoff due to thin vegetation cover (Djamali et al., 2008a). Bottema (1995) also reported more influx of eroded mineral from the mountains surrounding Lake Van in eastern Anatolia during periods with lower AP values. Our data suggest a relatively dry climate for the area during the period 2555-1474 cal BP. However, intensified agro-sylvo-pastoral practices could also have been responsible for the sparse regional vegetation ascribed to this period.

For the Late-Holocene, more pronounced aridity is also inferred from lake records in the Middle/Near East at about 3000 cal BP. Arid conditions were reconstructed on the basis of stable isotope analysis and detailed lithological, mineralogical, and palynological data (Migowski et al., 2006; Stevens et al., 2006; Neumann et al., 2007). Wick et al. (2003) suggest more arid conditions between 4000 and 2060 cal BP and a shift towards more continental conditions with less precipitation as a result of this climatic change in the Lake Van area, eastern Anatolia. Marine isotope records from the
Mediterranean Sea also show drier climatic conditions for the period 3000-2000 BP (Schilman et al., 2001). Eski Acigöl record (central Anatolia) also indicates increasing aridity with lower lake levels from 3100 to 2700 cal BP (Roberts et al., 2011). In Eastern Mediterranean and Turkey, lake sediments, pollen, and stable isotopes reveal that arid conditions prevailed after $3000 \mathrm{cal} \mathrm{BP}$, ending around 2100-2000 cal BP (Roberts et al., 2008, 2011; Wick et al., 2003; Kuzucuoğlu et al., 2011). The expansion of dry climatic conditions, stretching from Turkey to Arabian Peninsula at about 3000 cal BP, may have reached to NW Iran, as shown by the new SK pollen record.

\subsubsection{Period between 1474 and $557 \mathrm{cal} \mathrm{BP}(102-41 \mathrm{~cm})$}

The pollen composition of this period indicates the expansion of arboreal vegetation (Figs. 3 and 5), particularly oak, in the area. Lamy et al. (2006) and Neumann et al. (2007) have reported an increase in rainfall and lake level of Black Sea, Red Sea and Dead Sea after 2000 cal BP. The mineralogy and grain-size distribution of sediments from Tecer Lake, central Anatolia, also suggest episode of relatively high lake level and humidity from 1450-1100 cal BP (Kuzucuoğlu et al., 2011). Wetter and/or warmer climatic conditions from 1500-1000 cal BP have been postulated for the Hyrcanian region of northern Iran (Ramezani et al., 2008; Khakpour Saeej et al., 2013; Leroy et al., 2013) and for Colchis in western Georgia (Connor, 2011). This inferred climatic condition seems to have been responsible for the expansion of gallery forests along the coasts of the latter area (Kvavadze, 1982 in Connor, 2011).

A sharp decline of Quercus and rising values of ARTEMISIA may indicate a relatively dry period between 1088 and 813 cal BP, which correlates fairly well with a drop of the lake level (see Section 4.3) (Figs. 4 and 5). This period coincides with the Medieval Climatic Anomaly (MCA), a period of warmer and/or wetter climate in the Eastern Mediterranean (Kaniewski et al., 2011; Kuzucuoğlu et al., 2011; Woodbridge and Roberts, 2011; Roberts et al., 2012) and a dry and/or colder climate in northern Iran (Ramezani et al., 2008). In the Lake Tecer record (Kuzucuoğlu et al., 2011), the humid period between 1450-1100 cal BP was immediately followed by an increase in dryness and lowering of the lake level. It seems that in Lake Urmia basin, with its more continental location, the MCA was experienced as a warmer climate, which may have triggered more evaporation from the lake surface. Palaeoclimatic reconstructions show a decline in temperatures for the Northern Hemisphere from 950 cal yr BP. Furthermore, there is evidence for widespread hydrological anomalies from 1050 to 650 cal BP (Bradley et al., 2003). Based on increased $\delta^{18} \mathrm{O}$ values in Lake Zeribar's ostracods, Stevens et al. (2006) proposed a slight increase in aridity for western Iran at $1000 \mathrm{cal} \mathrm{BP.}$

Climate was probably not the only driving force on vegetation and regional hydrology. This period corresponds to invasions by central Asian nomadic people, particularly the Mongols. Low values of pollen types attributable to cultivated trees and ruderal plants, along with CENTAUREA SOLSTITIALIS TYPE suggest a decline in agricultural/ arboricultural activities and increased pastoralism and deforestation in the area. These factors could have collectively hampered forest regeneration and, on the other hand, favoured the expansion of Artemisia in steppe vegetation.

\subsubsection{7 cal BP-present ( $41 \mathrm{~cm}$-top of the core)}

The last $c a$. 500 years are characterized by the virtual disappearance of QuERCus and increased values of most NAP types (Fig. 5). The onset of this period was probably coincident with the Little Ice Age (LIA). Signals of the occurrence of this event during 700-150 BP have been reported in the Eastern Mediterranean (Woodbridge and Roberts, 2011), and northwestern (Djamali et al., 2009a) and northern Iran (Ramezani et al., 2008; Leroy et al., 2011; 
Naderi Beni et al., 2013). High values of MS could be indicative of increased soil erosion and siliciclastic input into the site, due to both intensified grazing activities and more torrential precipitation. Meanwhile, an episode of high lake level is suggested by low values of wetland types (Fig. 4). Djamali et al. (2009a) suggest that lower summer temperatures and higher annual precipitation may have caused a higher water level in Lake Almalou, some $120 \mathrm{~km}$ east of Urmia, during the LIA. In addition, an increase in rainfall in the catchment basin of the Caspian Sea is considered to be responsible for a higher sea level during the LIA (Leroy et al., 2011; Naderi Beni et al., 2013). In several Eastern Mediterranean records (e.g. Kuzucuoğlu et al., 2011; Woodbridge and Roberts, 2011), evidence of increased precipitation and cold climate can be found during the 700-150 BP time interval.

The inferred high levels of Lake Urmia may thus partly be explained by lower evaporation during the cooler summers of the LIA and a more sustained and continuous yearly supply of meltwater from the mountain snow and glaciers. The low values of AP during this period in our pollen record may also be ascribed to higher anthropogenic pressure on the forest ecosystems due to the change in the lifestyle of human communities living on the high plateaus of northwestern Iran and eastern Anatolia. It seems that the increased precipitation and long-lasting snow cover in the high elevations due to the lower annual temperatures of the LIA may have favoured a more nomadic lifestyle (Djamali et al., 2009a).

\subsection{Anthropogenic evidence}

\subsubsection{Arboricultural practices}

The very first signal of arboricultural activities in SK pollen record can be inferred from the occurrence of VITIS at the beginning of the record, i.e. around 2555 cal BP. As VITIS is normally extremely under-represented in pollen diagrams, even its low values may point to local vineyards (Djamali et al., 2009a); hence, viticulture is likely to have been practiced in the Lake Urmia area over the entire record. In a palynological study of Lake Almalou in NW Iran, the first occurrence of VITIS dates back to 3000 cal BP, showing that viticultural activities in northwestern Iran began at least as early as the Iron Age (Djamali et al., 2009a). Other palynological records from the Eastern Mediterranean also indicate that cultivation of fruit trees began in mountains of southwestern Turkey at 2300 cal BP and in Lake Van area at 2100 cal BP (Wick et al., 2003; Finné et al., 2011).

Another intriguing finding of our study is the occurrence of Ricinus Communis dating back to ca. 2230 cal BP. Bottema (1986) also found Ricinus in the late Holocene, but the first appearance of this pollen was not precisely dated. In Lake Almalou pollen record, this type was first encountered only at 400 cal BP. Our finding may thus suggest an earlier history of Ricinus communis cultivation along the western shores of Lake Urmia compared to the eastern part. Our data bring into question the postulation of Djamali et al. (2009a) that attributed the transportation of this plant species from Africa or India to the Ottoman Empire (13th to late 19th centuries) since the Safavid Period (the early 16th to mid 18th centuries). Our new data instead suggest the existence of trade links between Africa or India dating back to the Iron Age.

JugLANS, which was first observed in the SK record at about 2100 cal BP, gradually increased and peaked between 1280 and 850 cal BP. Similarly, the first occurrence of Juglans pollen in Lake Almalou was recorded at about 2100 cal BP and started to increase from 1600 cal BP (Djamali et al., 2009a). However, findings from southwestern Iran (Lake Maharlou) indicate an earlier history of Juglans cultivation, suggested by the first appearance of its pollen type dating back to 4500 cal BP (Djamali et al., 2011).
In contrast to the Lake Almalou sequence (Djamali et al., 2009a, 2011), where a prominent agricultural phase dated to $c a$ 2450-2220 cal BP (i.e. concurrent with Achaemenid Empire) is recorded, our record does not clearly show such agricultural activities for western Lake Urmia. The persistent low values (i.e. less than 3\%) for cultivated taxa in this period (Fig. 5), may indicate fairly enhanced agricultural activities compared to 1400 cal BP. Only after 1400 cal BP (i.e. during the Sasanian Empire), arboriculture started to develop in the region, as was also shown by Djamali et al. (2009a) for the Lake Almalou area.

The appearance of OLEA during the period 1280-1450 cal BP may point to the local occurrence of Olea trees or olive cultivation in remote areas, such as southern Turkey. Olea pollen can easily be transported over long distances (Djamali et al., 2009a). The subsequent demise of arboricultural practices in the area represented by the SK record may be linked to invasion of nomadic people from central Asia between 13th and 16th centuries. However, the effect of drier climatic conditions during the LIA may not be ruled out. The re-expansion of agricultural activities in the area coincides with the Safavid Era. The modern period, represented in zone SK1-C since $c a$. 550 cal BP (Fig. 3), is marked by developed agricultural activities and intensified human interference in the area.

\subsubsection{Other agro-pastoral pollen indicators}

A clear correlation exists between the curves representing ruderal plants and cultivated trees in the SK record after 1400 cal BP (Figs. 3 and 5). Centaurea solstitialis and Plantago lanceolata-type pollen show increased values since 1400 cal BP. Bottema and Woldring (1990) and Djamali et al. (2009a) stated that CENTAUREA Solstitialis TYPE is usually produced by plants associated with cereal cultivation in circum-Mediterranean and Near Eastern regions. According to van Zeist and Bottema (1977), this pollen type is produced by a great number of Centaurea species, which are mostly found in disturbed habitats such as farmlands and roadsides. However, some species originally formed part of steppe vegetation in northwestern Iran (van Zeist and Bottema, 1977). In the SK record, CentaureA SOLSTITIALIS-TYPE is largely concurrent with PlanTAGo LANCEOLATA-TYPE and can be considered primarily as an indicator of human activities.

Being produced by ruderal plants, RUMEX ACETOSA-TYPE pollen shows relatively high values after 1280 cal BP, which coincides with intense cultivation activities during the Sasanian Empire. However, its values fade out at $24 \mathrm{cal}$ BP (15 cm depth). The overall low percentages of this sensitive thin-walled pollen type in the SK pollen record can be attributed to variable preservation conditions in this marginal pond due to frequent lake-level fluctuations.

\subsection{Hydrological changes of the SK wetland area}

Changes in wetland vegetation can be related to water level fluctuation. Local vegetation is largely controlled by the local hydrology in the wetland site, variations in which are intertwined with lake-level changes.

The SK pollen diagram of Wetland and saline habitat types (Fig. 4) starts with pollen zone SK1-1 (approximately the period 2555-1749 cal BP; $175-121 \mathrm{~cm}$ ), representing relatively high values of halophyte and halo-tolerant species. As previously mentioned, the climate of this period might have been relatively arid with steppe vegetation in the catchment of Lake Urmia, as indicated by extremely high values of ARTEMISIA and the occurrence of Asteroideae, Cichorioideae, Caryophyllaceae, Brassicaceae and MatricARIA-TyPe (van Zeist and Bottema, 1977; Joannin et al., 2014). The persistent and relatively high frequency of pollen types attributable to hydrophyte species e.g. Sparganium and Cyperaceae, suggest that a well-established reed-swamp vegetation occurred around the coring site during this period. However, the curves 
representing CyPeraceae and SPARgAnIUM-Type are, to some degree, parallel with those of ChenopodiaceAe-TYPe and PoAceAe. The high values of CHENOPODIACEAE-TYPE could be attributed to the expansion of corresponding plant taxa on the temporarily exposed shores of the lake. Also it is quite likely that some of the POACEAE pollen could stem from grasses that formed part of the marsh vegetation belt around the lake, as is the case today. Similarly, the rather high values of TAMARIX (Fig. 3), a pollen type produced by halophytic tamarisk shrubs, which grow today on the lake shores, can be considered as an arboreal indication of lake level drop.

The RIELLA curve shows a considerable peak at about 1900 cal BP (Fig. 5), corresponding to the decline of other wetland and saline habitat types. The germination and growing of Riella requires the ephemeral flooding of a flat area by shallow, brackish water and bottom sediments dominated by muds. Thus the above peak of RIELLA might indicate short-lived flooding events during the spring time when Riella plants are most frequently observed to germinate and colonize the shallow water habitats in the Mediterranean region. Very short spring rainfall events may have not been sufficient to cause major changes in the regional vegetation.

In zones SK1-2 (1749 to $1088 \mathrm{cal} \mathrm{BP;} 121-73 \mathrm{~cm}$ ) and SK1-4 (813 to -34 cal BP; $53-22 \mathrm{~cm}$ ), previously abundant wetland types decline substantially, possibly as a result of the contraction of marsh vegetation belt following a rise in lake level. As Amaranthaceae develop extensively on the saline plains around the lake, the decrease of CHENOPODIACEAE-TYPE in the pollen record may reflect the inundation of the site following a rise in lake water-level. Similarly, the decline of macrophytes (as for instance can be inferred from decreased SPARGANIUM-TYPE) could be taken as another indication of high lake-level over this period. High lake-level may also be inferred from low values of OM in this zone.

The abundance of most wetland types with relatively high values of TAMARIX (Fig. 3) in zone SK1-3 (1088-813 cal BP; $73-53 \mathrm{~cm}$ ) may reflect a drop in lake level. The prominent peaks of CHENOPODIACEAE-TYPE, as well as the clumps of this pollen type, imply that close to the sampling site, soil and physiographic conditions offered a suitable habitat for halophyte and halo-tolerant plants. The majority of types of uncertain habitats show substantial values during this period. Their corresponding plant producers are mainly insect-pollinated (Caryophyllaceae, Asteraceae and Brassicaceae) and/or possess heavy pollen grains (Plumbaginaceae). It can be concluded that these types were reworked from the surrounding uplands to the deposition site, as the high values of sand and sharp rock fragments indicate (Fig. 4). The relatively high values of $\mathrm{CaCO}_{3}$ in the sediments during this and the next zone (Fig. 5) could partly be explained by the geological structure of the lake catchment area (see Section 2.1), as eroded limestone could contribute part of the calcium carbonate to the sediment. However, another possible explanation is that the $\mathrm{CaCO}_{3}$ comes from the dissolved carbonate in the springs feeding the wetland. Such springs are mostly of karstic origin and have a high content of calcium carbonate that may then be precipitated through the metabolic activities of plants in the wetland. In such a scenario, periods of low lake level can thus correspond with higher local concentration of $\mathrm{CaCO}_{3}$.

During the period from 813 to -34 cal BP (SK1-4; 53-22 cm), the lake shore must have been poorly vegetated, as all wetland types show negligible values. It seems that a rise in lake level inundated the coastal plains and precluded the expansion of wetland and halophytic vegetation. In his palynological analysis of a core from Lake Urmia, Bottema (1986) assigns the low values of $\mathrm{CaCO}_{3}$ during wet periods (highstands) to lake water dilution. In our study, however, no correlation could be established between calcium carbonate and the lake water-level, most probably because the studied wetland receives part of its water from underground springs rather than lake water, locally modifying the dominant Lake
Urmia water chemistry. High values of MS in the middle of this period probably indicate the deposition of detrital siliciclastic materials derived from inflowing rivers in deeper lake water. Macroscopic charcoal particles occur abundantly in the middle of this zone, indicating that local fires may have initiated detrital input through destabilization of vegetation cover and subsequent soil erosion. This period corresponds to the LIA, when the Caspian Sea experienced a prominent highstand (Kroonenberg et al., 2007). Both Leroy et al. (2011) and Djamali et al. (2009a,b) propose higher water levels during the LIA for the Caspian Sea and Lake Almalou, respectively.

The most recent period (zone SK1-5, -34 to -5 cal BP) corresponds with organic accumulation at the coring site and a rise in MS and $\mathrm{CaCO}_{3}$ values, particularly in the uppermost samples (Fig. 5). The ample expansion of reed vegetation, particularly Poaceae, Cyperceae, and Amaranthaceae on the surface of the pond must have been responsible for the considerable amounts of OM. However, organic matter diagenesis (i.e. the consumption of organic material by microbial action) in the lower sections of the core may also explain elevated OM values at the surface. Less water input to the lake may have caused more concentration of $\mathrm{CaCO}_{3}$ in the spring waters feeding the wetland and the lack of seasonal floodings and thereby the disappearance of Riella. Djamali et al. (2008b) found RIELla spores even in the topmost $1 \mathrm{~cm}$ of cores from Lake Urmia, suggesting that the plant occurs today around the lake, particularly in the extensive fresh and brackish water resources available during spring time. However, no species of Riella has so far been recorded from Iran (Djamali et al., 2008b). Indeed, intensive agricultural and land-use activities have dramatically limited suitable habitats for this plant.

\section{Conclusion}

This study presents a high-resolution record of the LateHolocene palaeoenvironmental changes in hypersaline Lake Urmia basin over the past 2550 years. Over the period 2550-1500 cal BP, a rather cold and dry climate, with treeless steppe vegetation, and low lake levels in Lake Urmia may have been the prevailing environmental condition in the region. The period $1500-550$ cal BP is marked by a prominent increase in oak, possibly as a consequence of combined effect of increased moisture availability and decreased agro-sylvo-pastoral practices. The Medieval Climatic Anomaly (1100-800 cal BP) is represented in our study by a sharp decline of QUERCus and high values of ARTEMISIA. Drier climatic conditions during this period may have triggered more evaporation from the water surface and lower lake levels. After the MCA, tree populations began to re-establish and steppic species population (e.g. Artemisia) decreased. Between 550 and 150 cal BP (LIA), a rise in Artemisia steppe and the occurence of an episode of high lake level suggest a cooler and a more arid climate.

Intensified human activity in the studied area can be inferred from the occurrence of VITIS at the beginning of this pollen record, which may imply the presence of viticulture in the surroundings of Lake Urmia since 2500 cal BP. Another possible indication for the early human presence near Urmia is the record of the pollen of Ricinus COMmunis at $c a .2230 \mathrm{cal}$ BP and that of Juglans at $2050 \mathrm{cal} \mathrm{BP}$. The curve for cultivated taxa culminates during the period 1280-810 cal BP, revealing that fruiticultural activities developed in the region during the dominance of Turkish-Persian dynasties such as the Seljuks Empire, which were prosperous periods in the history of Persia (Djamali et al., 2009a). A subsequent demise of arboricultural practices in the area is observed during the Mongol invasion (13th-14th centuries) until the beginning of 16th century. The re-expansion of agricultural activities in the area correlates to the Safavid Era (1501 AD-1736 AD). Intensified anthropogenic 
activities and general climate aridification over the last century must have been responsible for the substantial decrease in lake level, disappearance of Quercus and increased non-arboreal vegetation in the surroundings of southwestern Lake Urmia.

\section{Acknowledgments}

This work has been partly supported by the Iranian National Institute for Oceanography and Atmospheric Science (INIOAS) and the ERC FP7 project entitled 'Persia and its Neighbours: the Archaeology of the Late Antique Imperial Power in Iran'. Numerous useful comments proposed by A. Sharifi (University of Miami) and two anonymous reviewers have substantially improved the quality of the work. We are also grateful to S. Connor (Melbourne University) for correcting the English and providing enormous valuable comments and suggestions.

\section{References}

AghaKouchak, A., Norouzi, H., Madani, K., Mirchi, A., Azarderakhsh, M., Nazemi, A. Nasrollahi, N., Farahmand, A., Mehran, A., Hasanzadeh, E., 2015. Aral Sea syndrome desiccates Lake Urmia: call for action. Journal of Great Lakes Research 41 (1), 307-311.

Akhani, H., 2008. Taxonomic revision of the genus Salicornia L. (Chenopodiaceae) in Central and Southern Iran. Pakistan Journal of Botany 40 (4), 1635-1655.

Anonymous, 2012. The drying of Iran's Lake Urmia and its environmental consequences. Article reproduced from United Nations Environment Programme (UNEP) Global Environmental Alert Service (GEAS). Environmental Development 2, 128-137.

Asem, A., Eimanifar, A., Djamali, M., De los Rios, P., Wink, M., 2014. Biodiversity of the Hypersaline Urmia Lake National Park. Diversity 6, 102-132.

Asri, Y., 1999. Vegetation of the Orumieh Lake Salt Marshes. Research Institute of Forests and Rangelands, Tehran.

Asri, Y., Ghorbanli, M., 1997. The halophilous vegetation of the Orumieh lake salt marshes, NW, Iran. Plant Ecology 132 (2), 155-170.

Beaulieu, J.L., Andrieu, V., Reille, M., Gruger, E., Tzedakis, K., Svobodova, H., 2001. An attemp of correlation between the pollen sequence and the middle Pleistocene stratigraphy from Central Europe. Quaternary Science Reviews 20, 1593-1602.

Beug, H.J., 2004. Leitfaden der Pollen bestimmung für Mitteleuropa und Angrenzende Gebiete. Verlag Dr. Friedrich Pfeil Publications, Germany.

Blaauw, M., Christen, A., 2011. Flexible Paleoclimate age-depth models using an Autoregressive Gamma process. Bayesian Analysis 69 (3), 457-474.

Bottema, S., 1986. A late Quaternary pollen diagram from Lake Urmia (northwestern Iran). Review of Palaeobotany and Palynology 47, 241-261.

Bottema, S., 1995. Holocene vegetation of the Van area: palynological and chronological evidence from Sogutlu, Turkey. Vegetation History and Archaeobotany 4, 187-193.

Bottema, S., Woldring, H., 1990. Anthropogenic indicators in the pollen diagrams of the Eastern Mediterranean. In: Bottema, S., Entjes-Nieborg, G., van Zeist, W. (Eds.), Man's Role in the Shaping of the Eastern Mediterranean Landscape. Balkema, Rotterdam.

Bradley, R.S., Hughes, M.K., Diaz, H.F., 2003. Climate in medieval time. Science 302 404-405.

Connor, S.E. 2011. A Promethean Legacy: Late Quaternary Vegetation History of Southern Georgia, the Caucasus. In: Ancient Near Eastern Studies Supplement 34. Peeters Publishers, Louvain.

Cullen, H.M., deMenocal, P.B., Hemming, S., Hemming, G., Brown, F.H. Guilderson, T., Sirocko, F., 2000. Climate change and the collapse of the Akkadian empire: evidence from the deep sea. Geology 28, 379. http://dx.doi.org/ 10.1130/0091-7613(2000)28<379:CCATCO > 2.0.CO;2.

Djamali, M., de Beaulieu, J.L., Shah-Hosseini, M., Andrieu-Ponel, V., Amini, A Akhani, H., Leroy, S.A.G., Stevens, L., Alizadeh, H., Ponel, P., Brewer, S., 2008a. A late Pleistocene long pollen record from Lake Urmia, NW Iran. Quaternary Research 69, 413-420.

Djamali, M., Kürschner, H., Akhani, H., de Beaulieu, J.L., Amini, A, Andrieu-Ponel, V., Ponel, P., Stevens, L., 2008b. Palaeoecological significance of the spores of the liverwort Riella (Riellaceae) in a late Pleistocene long pollen record from the hypersaline Lake Urmia, NW Iran. Review of Palaeobotany and Palynology 152, $66-73$.

Djamali, M., de Beaulieu, J.L., Andrieu-Ponel, V., Berberian, M., Miller, N. Gandouin, E., Lahijani, H., Shah-Hosseini, M., Ponel, Ph, Salimian, M., Guiter, F. 2009a. A late Holocene pollen record from Lake Almalou in NW Iran: evidence for changing land-use in relation to some historical events during the last 3700 years. Journal of Archaeological Science 36 (7), 1364-1375.

Djamali, M., de Beaulieu, J.L., Miller, N., Andrieu-Ponel, V., Lak, R., Sadeddin, M. Akhani, H., Fazeli, H., 2009b. Vegetation history of the SE section of Zagros Mountains during the last five millennia; a pollen record from the Maharlo Lake, Fars Province, Iran. Vegetation History and Archaeobotany 18, 123-136.
Djamali, M., Akhani, H., Andrieu-Ponel, V., Braconnot, P., Brewer, S., de Beaulieu, J.L., Fleitmann, D., Fleury, J., Gasse, F., Guibal, F., Jackson, S.T., Lézine, A.M., Médail, F., Ponel, Ph, Roberts, N., Stevens, L., 2010. Indian Summer Monsoon variations could have affected the early-Holocene woodland expansion in the Near East. The Holocene 20 (5), 813-820.

Djamali, M., Miller, N.F., Ramezani, E., Andrieu-Ponel, V., De Beaulieu, J.L., Berberian, m, Guibal, F., Lahijani, H., Lak, R., Ponel, p, 2011. Note on arboricultural and agricultural practices in ancient Iran based on new pollen evidences. Paleorient 36 (2), 175-188.

Finné, M., Holmgren, K., Sundqvist, H.S., Weiberg, E., Lindblom, M., 2011. Climate in the eastern Mediterranean, and adjacent regions, during the past 6000 years a review. Journal of Archaeological Science 38, 3153-3173.

Fægri, K., Iversen, J., 1989. Textbook of Pollen Analysis, Third Revision (Revised by Fægri, K., Kaland, P.E. and Krzywinski, K.). John Wiley and Sons, New York.

Griffiths, H.I., Schwalb, A., Stevens, L.R., 2001. Environmental change in southwestern Iran: the Holocene ostracod fauna of Lake Mirabad. The Holocene 11 (6), 757-764.

Grimm, E.C., 2011. Tilia ver. 1.7.16. Illinois State Museum.

Heiri, O., Lotter, A.F., Lemcke, G., 2001. Loss on ignition as a method for estimating organic and carbonate content in sediments: reproducibility and comparability of results. Journal of Paleolimnology 25, 101-110.

Islamic Republic of Iran Meteorological Organization (IRIMO), 2015. Form 25, Data Processing Center. Available at: http://www.chaharmahalmet.ir/iranarchive.asp.

Issar, A.S., Ginat, H., Zohar, M., 2012. Shifts from deserted to inhabited terrain in the arid part of the Middle East, a function of climate changes. Journal of Arid Environments 86, 5-11.

Joannin, S., Ali, A., Ollivier, V., Roiron, P., Peyron, O., Chevaux, S., Nahapetyan, S., Tozalakyan, P., Karakhanyan, A., Chataigner, C., 2014. Vegetation, fire and climate history of the Lesser Caucasus: a new Holocene record from Zarishat fen (Armenia). Journal of Quaternary Science 29 (1), 70-82.

Joosten, H., Klerk, P., 2002. What's in a name? Some thoughts on pollen classification, identification, and nomenclature in quaternary palynology. Review of Palaeobotany and Palynology 122, 29-45.

Kaniewski, D., Van Campo, E., Paulissen, E., Weiss, H., Bakker, J., Rossignol, I., Van Lerberghe, K., 2011. The medieval climate anomaly and the little Ice Age in coastal Syria inferred from pollen-derived palaeoclimatic patterns. Global and Planetary Change 78, 178-187.

Katkar, N., 2011. Human palaeontology and prehistory (Palaeopopulations, palaeogenetics, migrations) after Last Glacial Maximum: the third migration. Comptes Rendus Palevol 10, 665-678.

Kelts, K., Shahrabi, M., 1986. Holocene sedimentology of Hypersaline Lake Urmia, northwestern Iran. Palaeogeography, Palaeoclimatology, Palaeoecology 54, 105-130.

Khakpour Saeej, M., Ramezani, E., Siyab Ghodsy, A.A., Zare, H., Joosten, H., 2013. Palynological reconstruction of 1500 years of vegetation history of Veisar (N Iran). Rostaniha 14 (2), 135-148 (in Persian with English abstract).

Klinge, J., Fall, P., 2010. Archaeobotanical inference of Bronze Age land use and land cover in the eastern Mediterranean. Journal of Archaeological Science 37. 2622-2629.

Kroonenberg, S.B., Abdurakhmanov, G.M., Badyukova, E.N., van der Borg, K., Kalashnikov, A., Kasimov, N.S., Rychagov, G.I., Svitoch, A.A., Vonhof, H.B., Wesselingh, F.P., 2007. Solar-forced 2600 cal BP and Little Ice Age highstands of the Caspian Sea. Quaternary International 173-174, 137-143.

Kuzucuoğlu, C., Dörfler, W., Kunesch, S., Goupille, F., 2011. Mid- to late-Holocene climate change in central Turkey: the Tecer Lake record. The Holocene 21 (1), 173-188.

Lamy, F., Arz, H.W., Bond, G.C., Bahr, A., Pätzold, J., 2006. Multicentennial-scale hydrological changes in the Black Sea and northern Red Sea during the Holocene and the Arctic/North Atlantic Oscillation. Paleoceanography 21 (1), PA1008. http://dx.doi.org/10.1029/2005PA001184.

Leroy, S.A.G., 2013. Natural hazards, landscapes, and civilizations. Treatise on Geomorphology 13, 190-203 (Geomorphology of Human Disturbances, Climate Change, and Natural Hazards).

Leroy, S.A.G., Lahijani, H.A.K., Djamali, M., Naqinezhad, A., Moghadam, M.V., Arpe, K., Shah-Hosseini, M., Hosseindoust, M. Miller, Ch.S, Tavakoli, V. Habibi, P. Naderi, M., 2011. Late Little Ice Age palaeoenvironmental records from the Anzali and Amirkola lagoons (south Caspian Sea): vegetation and sea level changes. Palaeogeography, Palaeoclimatology, Palaeoecology 302, 415-434.

Leroy, S.A.G. Kakroodi, A. Kroonenberg S, Lahijani, $H$, Alimohammadian, $H$, Nigarov, A., 2013. Holocene vegetation history and sea level changes in the SE corner of the Caspian Sea: relevance to SW Asia climate. Quaternary Science Reviews 70, 28-47.

Litt, T., Pickarski, N., Heumann, G., Stockhecke, M., Tzedakis, P.C., 2014. A 600,000 year long continental pollen record from Lake Van, eastern Anatolia (Turkey). Quaternary Science Reviews 104, 30-41.

Manzanilla, L. 1997. The impact of climatic change on past civilizations a revisionist agenda for further investigations. Quaternary International 43/44, 153-159.

Messager, E., Belmecheri, S., Von Grafenstein, U., Nomade, S., Ollivier, V., Voinchet, P., Puaud, S., Courtin-Nomade, A., Guillou, H., Mgeladze, A., Dumoulin, J., Mazuya, A., Lordkipanidze, D., 2013. Late Quaternary record of the vegetation and catchment-related changes from Lake Paravani (Javakheti, South Caucasus). Quaternary Science Reviews 77, 125-140.

Migowski, C. Stein, M., Prasad, S., Negendank, J.F.W., Agnon, A., 2006. Holocene climate variability and cultural evolution in the Near East from the Dead Sea sedimentary record. Quaternary Research 66, 421-431. 
Moore, P.D., Webb, J.A., Collinson, M.E., 1991. Pollen Analysis, second ed. Blackwell Science Publications, Oxford.

Munsell, A.H., 1975. Soil Color Charts. Munsell Color, Macbeth, Baltimore.

Naderi Beni, A., Lahijani, H., Moussavi Harami, R., Leroy, S., Shah-Hosseini, M., Kabiri, K., Tavakoli, V., 2013. Development of spit-lagoon complexes in response to Little Ice Age rapid sea-level changes in the central Guilan coast, South Caspian Sea, Iran. Geomorphology 187, 11-26.

Neumann, F.H., Kagan, E.J., Schwab, M.J., Stein, M., 2007. Palynology, sedimentology and palaeoecology of the late Holocene Dead Sea. Quaternary Science Reviews $26,1476-1498$.

Nourani, V., Sayyah Fard, M., 2012. Sensitivity analysis of the artificial neural network outputs in simulation of the evaporation process at different climatologic regimes. Advances in Engineering Software 47, 127-146.

Ponel, Ph, Andrieu-Ponel, V., Djamali, M., Lahijani, H., Leydet, M., Mashkour, M., 2013. Beetles as possible evidence for transhumance during the middle and late Holocene in the high mountains of Talysch (Talesh) in NW Iran? Environmental Archaeology 18 (3), 201-210.

Puche, F., Segarra-Moragues, J.G., 2013. Riella bialata Trab. (Riellaceae, Marchantiophyta): a new addition to the European liverwort flora. Cryptogamie, Bryologie 34, 341-352.

Punt, W., et al., 1976-2003. The Northwest European Pollen Flora I-VIII. Elsevier, Amsterdam vol. 1 (1976); vol. 2(1980); vol. 3 (1981); vol. 4 (1984); vol. 5 (1988); vol. 6 (1991); vol. 7 (1995); vol. 8 (2003).

R Development Core Team, 2013. R: a Language and Environment for Statistical Computing. R Foundation for Statistical Computing, Vienna, Austria. Available at: http://www.rproject.org/.

Ramezani, E., Marvi Mohadjer, M.R., Knapp, H.D., Ahmadi, H., Joosten, H., 2008. The late-Holocene vegetation history of the Central Caspian (Hyrcanian) forests of northern Iran. The Holocene 18 (2), 305-319.

Ramsar Sites Information Service, 2015 (rsis) Available at: https://rsis.ramsar.org/ ris/38? language $=$ en .

Rechinger, K.H., 1963-2010. Flora Iranica, vols. 1-178. Akademische Druck- und Verlagsanstalt, Graz.

Reille, M., Andrieu, V., de Beaulieu, J.L., Guenet, P., Goeury, C., 1998. A long pollen record from Lac du Bouchet, Massif Central, France, for the period ca 325 to 100 ka BP (OIS 9c to OIS 5e). Quaternary Science Review 17, 1107-1123.

Roberts, N., Jones, M.D., Benkaddour, A., Eastwood, W.J., Filippi, M.L., Frogley, M.R. Lamb, H.F., Leng, M.J., Reed, J.M., Stein, M., Stevens, L., Valero-Garce's, B. Zanchetta, G., 2008. Stable isotope records of Late Quaternary climate and hydrology from Mediterranean lakes: the ISOMED synthesis. Quaternary Science Reviews 27, 2426-2441.

Roberts, N., Eastwood, W., Kuzucuoğlu, C., Fiorentino, G., Caracuta, V., 2011. Climatic, vegetation and cultural change in the eastern Mediterranean during the midHolocene environmental transition. The Holocene 21 (1), 147-162.

Roberts, N., Moreno, A., Valero-Garcés, B.L., Corella, J., Jones, M., Allcock, S., Woodbridge, J., Morellón, M., Luterbacher, J., Xoplaki, E., Türkeş, M., 2012. Palaeolimnological evidence for an east-west climate see-saw in the Mediterranean since AD 900. Global and Planetary Change 84/85, 23-34.

Robinson, S.A., Black, S., Sellwood, B.W., Valdes, P.J., 2006. A review of palaeoclimates and palaeoenvironments in the Levant and Eastern
Mediterranean from 25,000 to 5000 years BP: setting the environmental background for the evolution of human civilization. Quaternary Science Reviews 25, 1517-1541.

Schilman, B., Bar-Matthews, M., Almogi-Labin, A., Luz, B., 2001. Global climate instability reflected by Eastern Mediterranean marine records during the late Holocene. Palaeogeography, Palaeoclimatology, Palaeoecology 176, 157-176.

Segarra-Moragues, J.G., Puche, F., Sabovljevic, M., 2012. Riella heliospora (Riellaceae) a new monoicous species of Riella subgenus Trabutiella from California. Systematic Botany 37, 307-319.

Shackley, M., 2006. Middle East and North Africa: Ancient Empires, Atlas of Travel and Tourism Development (Chapter 2). Elsevier Butterworth-Heinemann Publications, Netherlands.

Shahrabi, M., 1994. In: Hushmandzadeh, A. (Ed.), Seas and Lakes of Iran. Treatise on the Geology of Iran, pp. 9-81. Book No. 10.

Sima, S., Tajrishy, M., 2013. Using satellite data to extract volume-area-elevation relationships for Urmia Lake, Iran. Journal of Great Lakes Research 39, 90-99.

Snyder, J.A., Wasylik, K., Fritz, S.H.C., Wright Jr., H.E., 2001. Diatom-based conductivity reconstruction and palaeoclimatic interpretation of a 40-ka record from Lake Zeribar, Iran. The Holocene 11 (6), 737-745.

Stevens, L.R., Ito, E., Schwalb, A., Wright Jr., H.E., 2006. Timing of atmospheric precipitation in the Zagros Mountains inferred from a multi-proxy record from Lake Mirabad, Iran. Quaternary Research 66, 494-500.

Stevens, L.R., Djamali, M., Andrieu-Ponel, V., De Beaulieu, J.-L, 2012. Hydroclimatic variations over the last two glacial/interglacial cycles at Lake Urmia, Iran. Journal of Paleolimnology 47, 645-660.

Tsanova, T., 2013. The beginning of the Upper Paleolithic in the Iranian Zagros. A taphonomic approach and techno-economic comparison of Early Baradostian assemblages from Warwasi and Yafteh (Iran). Journal of Human Evolution 65 39-64.

Tudryn, A., Tucholka, P. Özgur, N., Gibert, E., Elitok, O., Kamaci, Z., Massault, M., Poisson, A., Platevoet, B., 2013. A 2300-year record of environmental change from SW Anatolia, Lake Burdur, Turkey. Journal of Paleolimnology 49, 647-662.

van Zeist, W., Bottema, S., 1977. Palynological investigations in Western Iran. Palaeohistoria 19, 19-85.

Wasylikowa, K., 2005. Palaeoecology of Lake Zeribar, Iran, in the Pleniglacial, Lateglacial and Holocene, reconstructed from plant macrofossils. The Holocene 15 (5), 720-735.

Wick, L., Lemcke, G., Sturm, M., 2003. Evidence of Lateglacial and Holocene climatic change and human impact in eastern Anatolia: high-resolution pollen, charcoal isotopic and geochemical records from the laminated sediments of Lake Van, Turkey. The Holocene 13, 665-675.

Woodbridge, J., Roberts, N., 2011. Late Holocene climate of the Eastern Mediterranean inferred from diatom analysis of annually-laminated lake sediments. Quaternary Science Reviews 30, 3381-3392.

Iran Water Resources Management (WRM), 2015. Available in: http://daminfo.wrm. ir/fa/tabularview? rnd $=28797$.

Zehzad, B., 1989. Flora and vegetation of Ashk Island (Urumia Lake National Park) Journal of Science (University of Tehran) 18, 57-64.

Zohary, M., 1973. Geobotanical Foundations of the Middle East. Gustav Fischer Verlag. 